\section{ELISABETH FRIIS}

\section{SAMTIDSPOESI I TILBAGEBLIK}

\author{
PETER STEIN LARSEN \\ Drømme og dialoger \\ To poetiske traditioner omkring 2000 \\ Odense, 2009 (Syddansk Universitets- \\ forlag). 560 Sider.
}

Peter Stein Larsens disputats, der bærer den poetiske, men nogenledes misvisende titel (hvis drømmen ikke er dialogisk, ja polylogisk, hvad er så?), Drømme og dialoger: To poetiske traditioner omkring 2000, må anses for et forsøg på at skrive dansk poesis historie i det 20. århundrede. Det erklærede formål er at godtgøre, "hvordan den nye danske lyrik ser ud betragtet som helhed" - "ny" vil her sige "omkring år 2000", men dette kræver for Peter Stein Larsen et historiserende greb tilbage $i$ det 20. århundredes danske poesi. En god del af bogen bruges simpelthen på en afdækning af samtidspoesiens litteraturhistoriske rødder.

Disputatsens hovedtese er, at hvis man anlægger en bachtiniansk optik på den heterogene masse af tekster, der i det 20. århundredes danske litteratur er blevet betegnet som "lyrik", så vil to klare paradigmer, hvorunder alle disse forskelligartede tekster lader sig indordne, komme til syne: Det monologiske og det dialogiske paradigme - en modstilling, som er hentet fra Bachtin, og som Peter Stein Larsen (herefter PSL) knytter til "en centrallyrisk", henholdsvis en "interaktionslyrisk" norm, som han hævder, at den danske digtning er udspændt mellem.

Jeg har af flere grunde glædet mig til at læse PSL's bog. En lyrikkens litteraturhistorie er et dristigt og løfterigt forehavende. Man kunne f.eks. forestille sig, at arbejdets fokus på den lyriske genre tegnede et andet billede af litteraturhistorien end det, som vi kender fra de genreinklusive forsøg på at bedrive denne så vanskelige og omdiskuterede genre, litteraturhistorie. Som Hans Magnus Enzensberger siger, er det lyrikkens store held, at den er så eksklusiv (få læsere, få fortolkere, nul kroner), for det betyder, at lyrikken end ikke forsøger at begå sig på markedets præmisser. Den bliver skrevet, fordi den må skrives, hvilket er en nødvendighed, som man måske ikke har alle de romaner, der fylder morgenavisernes bogtillæg, under mistanke for at lide af. PSL er dog mere optaget af lyrikkens kvantitative aspekter. De 5000 digitale digtsamlinger, der findes på nettet, kan "næppe indikere andet, end at den lyriske genre har det ganske godt” (9). Hvis man læser netpubliceret lyrik, kunne man nu føle sig fristet til at drage den modsatte konklusion, men fred være med det.

PSL's følelse for den lyriske genre er stor og begejstret, hvilket gør det så meget desto mere overraskende, at PSL vælger prosaens teoretiker, den notorisk lyrikfjendske Bachtin, som teoretisk ramme for sine undersøgelser, og endvidere plæderer for, at "interaktionslyrikken” har lært at være "social, interagerende og mangfoldig" af prosaen. PSL undskylder godt nok Bachtin med, at Ordet $i$ romanen er forfattet i Rusland i 1935-36, hvorfor hans 
kendskab til lyrik bestod af "spredte indtryk fra den symbolistiske, russiske epigondigtning samt visse avantgardister fra futurismens tidsalder" (50). Hvilke russiske digtere, PSL mere præcist forestiller sig, er dækket af denne artige kategorisering, er uvist, men det kunne jo f.eks. dreje sig om Blok, Mandelstam, Achmatova eller Majakovskij, digtere, hvis manglende kvalitet ikke er ganske indlysende for denne læser. Bachtin gik i gymnasiet og på universitetet for revolutionen (sovjetregimet har ikke bestemt hans horisont) og man kunne måske også forstille sig, at han havde læst Pusjkin? Min anke kan synes krakilsk, men dette er ikke et enestående eksempel på disputatsens grovmaskede omgang med de litterære traditioner, der ikke er vokset op af den danske muld. Den franske symbolismes interesse for forholdet mellem sproglig og musikalsk repræsentation afvises med et pennestrøg som "erkendelsesteoretisk uholdbar", og det hedder endvidere, at: "En årsag til, at digterne interesserer sig for musikken, er angiveligt den franske Mallarmé-kreds' næsten grænseløse forgudelse af Wagner.” (62). Så fik vi sandelig symbolismens komplekse udestående med musikken på plads.

Og når den i disputatsen i øvrigt allestedsnærværende Lars Bukdahl udnævnes til repræsentant for den amerikanske strømning, New Formalism (repræsenteret af bl.a. Dana Gioia, som i øvrigt er en mand), fordi han interesserer sig for rim og remser (376), så er bunden nået. New Formalism vil (i en reaktion på "ulæselig” poesi skrevet på frie vers) tilbage til de klassiske digtformer, det faste metrum og den slags, idet de antager, at disse former er mere tilgængelige for læserne. Lars Bukdahl som neokonservativ traditionalist?

Sådanne fejlagtige og forgrovede referencer udadtil er virkelig ærgerlige, men vi lader dem ligge for at se på sagen selv: Det billede bogen så tegner af den danske poesi. Og her er der heldigvis meget at hente.

En perspektivrig kvalitet ved Drømme og dialoger er f.eks. dens bestemmelse af begrebet "centrallyrik", der længe har svævet rundt i den danske litteraturforskning som en sært ubefæstet, i det højeste pragmatisk, kategori. Nu har vi fåt en definition at diskutere med.

Centrallyrikken har, får vi at vide, tre konstitutive træk (som PSL mestendels henter fra C.M. Bowras bog om den franske symbolisme: The Heritage of Symbolism (1943)): I. Det poetiske subjekt figurerer som et entydigt udsigelsescentrum i det poetiske univers. 2. Der dyrkes et poetisk særsprog, der er unikt og autentisk. 3. Digtet er afgrænset (har "værkkarakter") og har en utvetydig affinitet til et klassisk genrebegreb. Førende centrallyrikere er således f.eks. Klaus Rifbjerg, Henrik Nordbrandt, Søren Ulrik Thomsen, Pia Tafdrup og Morten Søndergaard.

Interaktionslyrikken (et begreb, der er PSL's eget) er derimod karakteriseret af "forskelligsprogethed" af "fremmede ord" - kort sagt ord fra forskelligartede sociale diskurser. Den er ikke monologisk, har ikke "værkkarakter" og sprænger de klassiske genredefinitioner. Hovedrepræsentanter er Pia Juul, F.P. Jac, Peter Laugesen, Klaus Høeck, Lars Bukdahl og Ursula Andkjær Olsen. 
Spørgsmålet er, om disse definitioner dækker fænomener, der faktisk findes i virkeligheden. Bogens overordnede greb er ikke at placere enkelte tekster, men hele forfatterskaber i disse kategorier, og endskønt PSL taler om "poler", som forfatterskaberne er udspændt mellem, så placerer han forfatterskaberne ganske håndfast $\mathrm{i}$ den ene eller den anden grøft, og holder det nu? Kategorierne kommer til at ligne en Prokrustesseng, man kommer hele tiden i tanker om andre tekster af de pågældende forfattere, tekster, der peger helt andre steder hen. Man kan også med rimelighed spørge til kriterierne for den "centrallyriske norm": Hvad er egentlig "et entydigt udsigelsescentrum"? Et "lyrisk Jeg" er vel netop en position i teksten, det er en plads, der kan indtages af hvem eller hvad som helst. Og hvad er et "autentisk" sprog? Også den centrallyriske kernegruppe, Tafdrup og Thomsen, arbejder med diskursblandinger i form af citater, direkte og indirekte, omvendinger af talemåder, talesprog og den slags. Hos Ole Sarvig blander religiøse diskurser sig med sekulære. En diskurs er altså en diskurs er en diskurs! - og den rene, autentiske tekst bliver svær at finde.

PSL's læsestrategi er i øvrigt karakteriserende og komparativ. Der males med bred pensel. I første omgang læser han "centrallyrik", så er det interaktionslyrikkens tur, hvorefter vi til sidst får en række sammenlignende "minilæsninger", som skal demonstrere, hvad der er henholdsvis centrallyrisk/ interaktionslyrisk i de enkelte digtes formsprog. De udvalgte tekster viser sig at svare vældig fint til de kriterier, der på forhånd er opstillet for, hvor- dan de forventes at opføre sig, og som f.eks. er opsummeret i følgende passus: "Modsat den romantisk-symbolistiske poet, der bekender sig til en ekspressiv poetik, hvor det poetiske sprog antages at udspringe af dybe, sjælelige kilder, opstår den avantgardistiske digters værk i en maksimal interaktion med en konkret sproglig omverden" (243).

PSL forsværger gentagne gange, at det skulle være hans ærinde at fælde værdidomme over den centrallyriske, henholdsvis den interaktionslyriske norm. Men hvorfor skal den centrallyriske digter så kaldes "poet", mens interaktionslyrikeren er "digter", hvorfor udspringer hans/hendes sprog af "dybe, sjælelige kilder", men interaktionslyrikeren er i kontakt med det konkrete? Det er en stærkt valoriseret beskrivelse, og dem er der mange af. Centrallyrikken er: "højstemt", "profetisk", "patosladet", "sakral", "autoritativ", mens interaktionslyrikken er "rå og hverdagslig", "slagfærdig", "anarkistisk", "mangfoldig", "heterogen" og "konkret”. Centrallyrikken er monologisk og uafhængig af de sociale omgivelser, interaktionslyrikken er dialogisk og afspejler den konkrete, sociale virkelighed i sine blandingsformer. PSL skriver med indlevelse om en masse centrallyriske digte, men det er, som om Bachtin-fælden, "lyrik er antisocial, udemokratisk og borgerlig, prosaen er demokratiserende, almen og magtkritisk", også klapper sammen om fremstillingens stilistiske niveau. Endskønt bogen slet ikke handler om forskellen mellem poesi og prosa, flytter Bachtins ideologiske nisser med - man forestiller sig, at portrættet af den danske samtidslyrik ville være blevet mindst li- 
ge så skarpt uden den monologisk/dialogiske tvedeling. Endskønt det retfærdigvis igen må nævnes, at PSL anfører, at kategorierne ikke er skarpt adskilte, så bruger han dem oftest, som om de var.

Disputatsen er fuld af læsninger af enkeltdigte, og der er mange gode karakteristikker af træk ved de mange forfatterskaber, der er under behandling. Herligt med så mange tekstlæsninger samlet $i$ en bog! Hvad disse mange læsninger angår, kan detaljerne i dem selvfølgelig altid diskuteres - og sådan må det være. Teksterne omtales i hovedsagen på et parafraserende niveau, og det må vel være måden at gøre det på, når man skal håndtere så stort og forskelligartet et stof. En sådan manøvre, hvor hele forfatterskaber kategoriseres ud fra ganske få teksteksempler, kræver dog også, at læseren kan stole på fortolkeren. Jeg skal afholde mig fra det allerværste flueknepperi, men må anholde to forhold: For det første fremgår det som regel ikke, om PSL citerer hele den tekst, han analyserer, eller blot uddrag af den. I sine betragtninger over Morten Søndergaards digt "Svanemølleværket" (424) afholder han sig ikke fra at konkludere om digtets samlede udsagn, skønt han ikke forholder sig til digtets afsluttende II linjer, hvis eksistens den læser, der ikke kender digtet i forvejen, ikke har en chance for at kende til - og som i øvrigt synes at pege væk fra den eksistentialistiske læsning, PSL leverer. PSL har det for det andet med at kønsbestemme de lyriske Jeg'er og Du'er, uden at der er noget som helst belæg for det $\mathrm{i}$ teksten. I den afsluttende analyse (468) af Pia Juuls tekst, "En klynge af frø- er”, fra sagde jeg, siger jeg (I999), læses et "psykisk smerteligt brud på et parforhold mellem en mand og en kvinde" ud af disse linjer: "En klynge af frøer / som du tror er hor / og jeg tror er børn / Det siger en del / om mig / at jeg gir dig ret / men mere om dig /at du skiller dem ad". "Manden” tænker på sex, kvinden på "reproduktion” må vist være logikken bag PSL's læsning, men det siger teksten ikke noget om, og hvad vi sidder tilbage med er en læsning, der kolporterer en stereotyp forestilling om kønnet, der kun kan være fortolkerens egen.

PSL må roses for at have medtaget en del knap så læste lyriske forfatterskaber, men alligevel rejser også spørgsmålet om tekstudvalgets repræsentativitet sig. Efterhånden som man får læst sig frem, begynder man at undre sig: Hvor er Inger Christensen, hvor er Per Højholt, og hvor er Dan Turell og Jørgen Leth? Niels Frank er også temmelig stedmoderligt behandlet. Hans-Jørgen Nielsen, hvor er du?

Hvad Inger Christensen angår, står der ganske vist en smule om Sommerfugledalen, men mon ikke Det og i hvert fald Alfabet snarere er, hvad der hypes på Forfatterskolen these days. For slet ikke at tale om, hvor utrolig læst Det var i 7oerne. Højholt er nævnt lidt hist og her, endskønt hans indflydelse har været kolossal. Dan Turèll er stort set ikke med. Det kan være udmærket at medtage Tore Ørnsbo, Claus Carstensen og Martin Glaz Serup, men når det nu er hensigten at tegne et billede af de traditioner, de strømninger, der har været prægende for samtidslyrikken, så må fravalget af ovenstående sværvægtere i det mindste begrundes. Disse for- 
fattere er vel ikke holdt op med at betyde noget for samtidslyrikken, fordi de har været så uheldige at dø eller er gået på skrivepension? Perspektivet er også begrænset i den forstand, at PSL ikke skriver noget om litterære rugekasser, miljøer, strømninger. Hans fremstilling er koncentreret om et eklektisk udvalg af enkeltdigte. Det er, som om Forfatterskolen, In the Making og Øverste Kirurgiske aldrig har fundet sted, ingen betydning har haft. I det hele taget er påvirkningen fra den amerikanske poesi ikke berørt. Peter Laugesens oversættelse af Gertrude Steins Tender Buttons og Lars Bukdahls oversættelse af Kurt Schwitters' Anna Blume nævnes som eksempler på den indflydelse, den klassiske avantgarde litteratur udøver på samtidsdigtningen. Men hvad med oversættelserne af John Ashbery, Kenneth Koch, Anne Carson - Lyn Heijinian? Niels Franks litteraturformidling, Martin Larsens, Basilisk? Som virkelig er pejlemærkerne for så mange af de nye digtere.

Man bliver vældig diskussionslysten under læsningen af Drømme og dialoger, og det er bogens store kvalitet. Alt $i$ alt bliver billedet af den danske lyrik omkring år 2000, til trods for at PSL mener at den har gyldighed "et godt stykke ind i fremtiden" (484), dog mere tilbageskuende end fremadrettet.

Elisabeth Friis er ekstern lektor ved Institut for Kunst- og Kulturvidenskab, Københavns Universitet. 